\title{
Lighting a candle in the dark: advances in the genetics and (gene) therapy of retinal dystrophies
}

\author{
Anneke I den Hollander \\ From 7th European Workshop on Immune-Mediated Inflammatory Diseases \\ Noordwijk aan Zee, the Netherlands. 28-30 November 2012
}

Retinal dystrophies cause severe visual impairment due to the death of photoreceptor and retinal pigment epithelium cells. These diseases until recently have been considered to be incurable. In the last two decades genetic studies have shed light on the molecular causes of several of these diseases, which has opened new avenues to develop therapeutic approaches. The mammalian eye has been at the forefront of therapeutic trials based on gene augmentation in humans with Leber congenital amaurosis, an early-onset recessive retinal dystrophy, due to mutations in the retinal pigment epithelium-specific protein $65 \mathrm{kDa}$ (RPE65) gene. Tremendous challenges still lie ahead to extrapolate these studies to other retinal disease-causing genes, as human gene augmentation studies require testing in animal models for each individual gene and sufficiently large patient cohorts for clinical trials remain to be identified through cost-effective mutation screening protocols.

Pharmacological approaches to antagonize retinal degeneration are also under development, including modulation of the immune system.

Published: 28 November 2012

Submit your next manuscript to BioMed Central and take full advantage of:

- Convenient online submission

- Thorough peer review

- No space constraints or color figure charges

- Immediate publication on acceptance

- Inclusion in PubMed, CAS, Scopus and Google Scholar

- Research which is freely available for redistribution

() 2012 den Hollander; licensee BioMed Central Ltd. This is an Open Access article distributed under the terms of the Creative Commons Attribution License (http://creativecommons.org/licenses/by/2.0), which permits unrestricted use, distribution, and reproduction in any medium, provided the original work is properly cited. 